\title{
In situ chemical composition of apatite in granitoids from the eastern Central Asian Orogenic Belt: A window into petrogenesis
}

\author{
Chen-YANG Sun ${ }^{1,2}$, Wen-LIANG XU ${ }^{1,3^{*}}$, XIAO-MING \\ ZHANG $^{1}$ \\ ${ }^{1}$ College of Earth Sciences, Jilin University, Changchun \\ 130061, China ("xuwl@jlu.edu.cn) \\ ${ }^{2}$ School of Earth, Atmosphere and Environment, Monash \\ University, Melbourne, VIC 3800, Australia \\ ${ }^{3}$ Key Laboratory of Mineral Resources Evaluation in \\ Northeast Asia, Ministry of Natural Resources of China, \\ Changchun 130061, China
}

Apatite, $\mathrm{Ca}_{5}\left(\mathrm{PO}_{4}\right)_{3}(\mathrm{~F}, \mathrm{Cl}, \mathrm{OH})$, is a common accessory mineral that formed in an early phase of crystallization within the magma. Most of the trace elements concentrated by substitution reactions in apatite $\mathrm{Ca}$ atom lattice are sensitive to changes in crystallization environment and thus effective in investigating the petrogenesis. This time, we present new geochemical data of apatite in granitoids from the eastern Central Asian Orogenic Belt (the Erguna and Xing'an massifs) to decipher the nature of magma source and its relationship to host rocks.

The partition coefficient and the composition of parental melt always constitute the significant controls on apatite REE patterns. However, the early crystallization of plagioclase, sphene, and allanite should be considered the principal causes that lead to the depletion in apatite REE patterns. Notably, the granitoids sampled here are all formed in the calc-alkaline and weakly peraluminous environment where monazite is rare. Inconsistent with other research, there is a weak relationship between the aluminum saturation index (ASI, also represented by ACNK) and apatite geochemistry in this study, which may be due to the lower crustal maturity of eastern Central Asian Orogenic Belt relative to other highly-evolved areas.

Several previous research and our result all have shown a strong correlation of $\mathrm{Sr}$ content between apatite and wholerock; thus, an apatite/bulk rock partition coefficient of $\mathrm{Sr}$ is calculated. Moreover, some trace elements of apatite provide a vital bond to adakitic rock, a discriminant diagram for adakitic rock by apatite geochemistry is therefore put forward in our paper.

This study was financially supported by the National Natural Science Foundation of China (Grant No. 41772047). 